\title{
A midface swelling in a child - A possible diagnostic dilemma
}

\author{
Kuntal Patel MRCS ${ }^{1}$, Deemesh Oudit MRCSEd ${ }^{2}$, G Ross MRCS ${ }^{2}$, Caroline Nicolson ${ }^{3}$, AJ Howcroft FRCS ${ }^{1}$
}

K Patel, D Oudit, G Ross, C Nicolson, AJ Howcroft. A midface swelling in a child - A possible diagnostic dilemma. Can J Plast Surg 2005;13(4):207-208.

A lump on the midface of a child can pose as a diagnostic dilemma. There is a wide variety of possible differential diagnoses, ranging from simple benign conditions such as a sebaceous cyst, dermoid cyst, lipoma, neuroma and neurofibroma, to potentially devastating conditions such as odontogenic myxoma.

A case of a child in which the formulation of a definite diagnosis was clinically and histologically challenging is presented.

Key Words: Dental follicle; Facial swelling; Odontogenic myxoma; Unerupted tooth

\section{Un œdème du plan sagittal chez un enfant : Un possibilité de dilemme diagnostique}

\begin{abstract}
Une bosse du plan sagittal chez un enfant peut constituer un dilemme diagnostique. Il existe toute une série de diagnostics différentiels possibles, en passant par de simples troubles bénins comme un kyste sébacé, un kyste dermoïde, un lipome, un névrome ou un neurofibrome jusqu'à des pathologies au potentiel dévastateur, comme un myxome odontogène. Le cas d'un enfant pour qui la formulation d'un diagnostic définitif constituait un défi clinique et histologique est présenté.
\end{abstract}

\section{CASE PRESENTATION}

A two-year-old girl was seen with a lesion in the region of the left nasolabial groove, which appeared over a period of four months. It was noted to gradually increase in size over this time period.

On clinical examination, the lesion was cystic and immobile, but did not seem to be attached to the overlying skin. There were no palpable cervical lymph nodes. A computed tomography scan of the facial bones showed an expanding lesion on the left side of the face at the junction of the nose and maxillary sinus that did not appear to be arising from the bone. A working diagnosis of a dermoid cyst was considered at that stage. Intraoperatively, contrary to the radiological findings, the lesion was found to be firmly attached to the periosteum of the maxilla. The contents were of a gelatinous nature.

Histopathological examination of the specimen showed vascular and cellular collagenous tissue. No cartilage or epithelial tissue was seen (Figure 1). The appearances were of a benign lesion. Immunohistochemical stains were not particularly helpful in attempting to arrive at a diagnosis. It was difficult to determine whether the lesion was an odontogenic myxoma or a developmental lesion associated with an unerupted tooth. However, after further specialist opinion, the lesion was diagnosed as a dental follicle associated with an unerupted tooth.

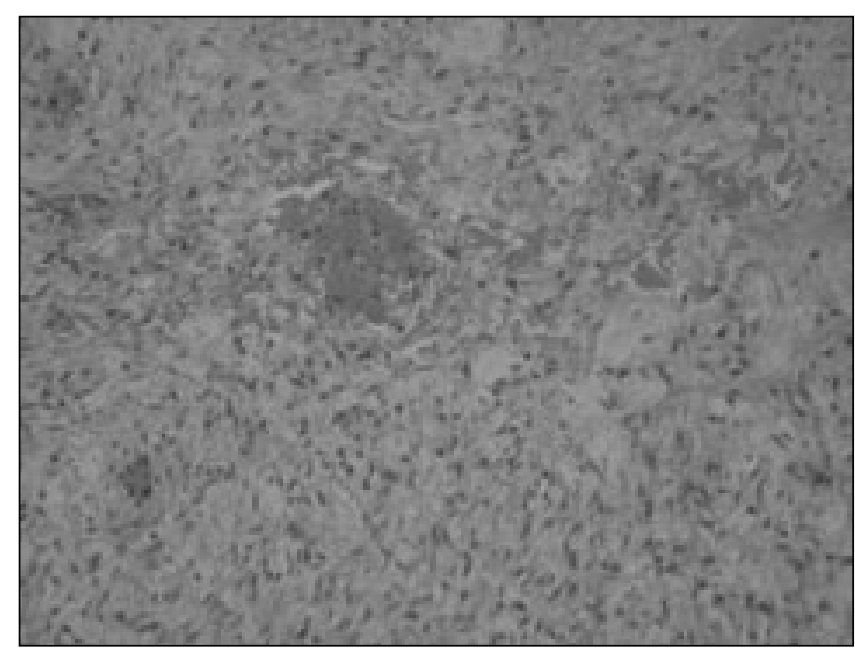

Figure 1) Histological appearance of the lesion, showing homogenous vascular and cellular collagenous tissue

\section{DISCUSSION}

Midface swellings in children account for about 2\% of all head and neck swellings (1). Differential diagnoses include simple lesions such as a sebaceous cyst, dermoid cyst and dental follicle, as well as more sinister conditions such as myxoma.

${ }^{1}$ Department of Plastic and Reconstructive Surgery, Lancashire Teaching Hospitals, Royal Preston Hospital, Preston; ${ }^{2}$ Department of Plastic and Reconstructive Surgery, South Manchester University Hospital, Wythenshawe Hospital, Southmoor Road, Manchester; ${ }^{3}$ Department of Pathology, Royal Preston Hospital, Preston, United Kingdom

Correspondence: Mr Deemesh Oudit, Department of Plastic and Reconstructive Surgery, South Manchester University Hospitals, Wythenshawe Hospital, Southmoor Road, Manchester M23 9LT, United Kingdom. Telephone 0161-998-7070, fax 0161-291-6381,

e-mail deemeshoudit@hotmail.com 
Although this lesion was a dental follicle associated with an unerupted tooth, it was difficult to rule out an odontogenic myxoma, even following the initial histological examination.

Myxomas are benign, slow-growing neoplasms derived from mesenchyme. While these tumours most frequently occur in the myocardium, the other sites most commonly affected are the maxilla and mandible. Nevertheless, myxoma is a very uncommon lesion of the midface, particularly in the pediatric population. Cases of odontogenic myxoma have been previously reported in the literature in the pediatric population. However, no case has been reported, to our knowledge, in which odontogenic myxoma presented as a diagnostic dilemma with a dental follicle.

Myxoma of the jaw is a rare benign tumour that has a tendency for bone destruction, invasion into surrounding structures and a relatively high recurrence rate. Maxillary myxoma is less frequent but behaves more aggressively than in the mandible because it spreads through the maxillary sinus. Cytologically, it should be differentiated from other

\section{REFERENCES}

1. Rotenberg BW, Daniel SJ, Nish IA, Ngan BY, Forte V. Myxomatous lesions of the maxilla in children: A case series and review of management. Int J Pediatr Otorhinolaryngol 2004;68:1251-6.

2. Kumar N, Jain S, Gupta S. Maxillary odontogenic myxoma: A diagnostic pitfall on aspiration cytology. Diagn Cytopathol 2002;27:111-4.

3. Wachter BG, Steinberg MJ, Darrow DH, McGinn JD, Park AH. Odontogenic myxoma of the maxilla: A report of two paediatric cases. Int J Pediatr Otorhinolaryngol 2003;67:389-93.

4. MacDonald-Jankowski DS, Yeung RW, Li T, Lee KM. Computed tomography of odontogenic myxoma. Clin Radiol 2004;59:281-7. tumours showing predominant myxoid change. Awareness of potential diagnostic pitfalls, and careful evaluation of clinical and radiological data are necessary to narrow the differential diagnosis (2). Myxoma is a very uncommon lesion of the midface, particularly in the pediatric population (3). The intraoral soft tissue myxoma or peripheral myxoma is a rare, slowly growing, benign mesenchymal tumour. Pathologically, it may be difficult to differentiate from other tumours with myoxid stroma and can occasionally be misinterpreted as a malignancy $(4,5)$. Radical surgery using resection of the tumour with a safe margin is advocated for odontogenic myxomas (6-8), hence the clear need for an accurate diagnosis.

\section{CONCLUSION}

Midface swelling in the pediatric population seldom poses a diagnostic dilemma. However, thorough clinical and histological evaluation is essential in ruling out odontogenic myxoma to prevent subsequent consequences.

5. Ramaraj PN, Shah SP. Peripheral myxoma of maxilla. A case report. Indian J Dent Res 2003;14:67-9.

6. Sharma R, Marwah N, Bedi RS, Bala S, Singh S, Arora B. Odontogenic myxoma of the mandible: a case report. Indian J Pathol Microbiol 2003;46:84-6.

7. Tamme T, Soots M, Kulla A, et al. Odontogenic tumours, a collaborative retrospective study of 75 cases covering more than 25 years from Estonia. J Craniomaxillofac Surg 2004;32:161-5.

8. Simon EN, Merkx MA, Vuhahula E, Ngassapa D, Stoelinga PJ. Odontogenic myxoma: A clinicopathological study of 33 cases. Int J Oral Maxillofac Surg 2004;33:333-7. 